\title{
Prophylactic Calcium and Vitamin D Supplementation to Prevent Hypocalcemia Post-Thyroidectomy
}

\author{
Vadala Satish Chandra Reddy ${ }^{\circledR}$, B Vijay ${ }^{\circledR}$ \\ Assistant Professor, Department of General Surgery, Bhaskar Medical College, Yenkapally, Moinabad, Ranga Reddy District, Telangana, India.
}

\section{Abstract}

Background: Hypocalcemia is a common post-operative complication of Thyroidectomy. This study is aimed to evaluate and treat hypocalcemia after total thyroidectomy procedure with routine administration of oral calcium and vitamin D supplements. The aim of this study was to evaluate the clinical effectiveness of oral calcium and vitamin D administration in preventing hypocalcemia post-thyroidectomy. Subjects and Methods: This was a prospective randomized controlled study conducted on 50 patients undergoing total or near total thyroidectomy for benign or malignant disease over the period of one year from February 2017 to January 2018 at Department of General Surgery, Bhaskar Medical College, Yenkapally, Moinabad, Ranga Reddy District, Telangana, India. All the participants were randomly assigned to routinely receive or not receive oral calcium $(3 \mathrm{~g} / \mathrm{d})$ and vitamin D $(1 \mu \mathrm{g} / \mathrm{d})$ for 2 weeks. Hypocalcemia symptoms and signs and total serum calcium levels were monitored and compared between the 2 groups. Data were presented in the form of statistical tables and charts. SPSS software version 20 was used for statistical analysis. Results: The hypocalcemic symptoms were minimal in the supplement group but more severe in the group not receiving the supplement. Serum calcium levels decreased in both groups after surgery but recovered earlier in the supplement group. Conclusion: In reducing the incidence and severity of hypocalcemia after total thyroidectomy, routine administration of supplements containing oral calcium and vitamin D has been effective.

Keywords: Thyroidectomy, Hypocalcemia, Post-surgery, Prevention, Prophylaxis, Oral calcium, Vitamin D

Corresponding Author: Vadala Satish Chandra Reddy, Assistant Professor, Department of General Surgery, Bhaskar Medical College, Yenkapally, Moinabad, Ranga Reddy District, Telangana, India.

E-mail: dr.satishreddy@gmail.com

Received: 21 November 2019

Revised: 12 January 2020

Accepted: 19 January 2020

Published: 30 June 2020

\section{Introduction}

Vitamin D and calcium are important health-related nutrients. Vitamin D helps the body to absorb calcium from foods and supplements. It also plays a role in helping muscles, nerves and the immune system to work properly. ${ }^{[1,2]}$ Calcium is a mineral that helps to maintain strong bones and teeth. ${ }^{[3,4]}$ The body requires calcium for the proper functioning of muscles, nerves and blood vessels. It is essential for hormones and enzymes which have an effect on many of the body functions. Thyroid surgery is one of the most frequently performed surgical procedures worldwide. In certain thyroid conditions, total thyroidectomy is an appropriate treatment. The most common complication resulting after this surgery is transient hypocalcemia - the incidence is $24 \%$ - which increases the morbidity rate and increases the length of stay in the hospital. ${ }^{[5]}$ In most cases, post-thyroidectomy hypocalcemia is temporary, but may take several months to resolve. Advances in surgical techniques have evolved to preserve the parathyroid gland function, which helps to prevent permanent hypocalcemia and its incidence now has reduced. However, transient hypoparathyroidism still occurs resulting in transient hypocalcemia. It occurs due to the age, parathyroid gland handling, devascularization, venous congestion, post-surgical local site edema and neck dissection. ${ }^{[6]}$ During the first 24 hours, bleeding is the main complication, but from the second day to six months, transient hypocalcemia is of main concern. Hypocalcemia can be evaluated symptomatically as well as from laboratory testing. Signs and symptoms of hypocalcemia include numbness, tingling and carpopedal spasm. Pre-operative and post-operative administration of oral calcium along with vitamin D prevents post-operative transient hypocalcemia after thyroidectomy. ${ }^{[7]}$ As transient hypocalcemia is common in post-thyroidectomy patients and increases the morbidity rate, giving vitamin $\mathrm{D}$ and calcium can reduce the burden of post-operative transient hypocalcemia. Routine oral calcium and vitamin D supplements have been proposed to prevent the development of symptomatic 
hypocalcemia and to increase the likelihood of early hospital discharge after bilateral surgical treatment of the thyroid gland.

\section{Subjects and Methods}

Place of Study: Department of General Surgery, Bhaskar Medical College, Yenkapally, Moinabad,RangaReddyDist.,Telangana, India.

Type of Study: This was a prospective randomized controlled study.

Sample size: 50 patients.

Sampling Methods: Consecutive sampling.

\section{Inclusion Criteria:}

All patients undergoing total or near total thyroidectomy for benign or malignant diseases were included in the study.

\section{Exclusion Criteria:}

Patients were excluded if they had any concomitant parathyroid disease, extensive lymph node dissection because of thyroid malignancy, toxic goiter, using calcium supplementation for any chronic disease before the operation, abnormal renal function and hypoalbuminemia.

\section{Statistical Methods:}

Data were presented in the form of statistical tables and charts. SPSS software version 20 was used for statistical analysis.

\section{Ethical Approval:}

Approval was taken from the Institutional Ethics Committee prior to commencement of the study.

\section{Results}

Fifty patients underwent total thyroidectomy. The ratio of males to females was 12:38, with a mean age of 45 years. Each group included 25 patients.

Comparison of serum test values (mean standard error of the mean) after totalthyroidectomy between groups with and without oral calcium and vitamin D supplements

\section{Discussion}

Fifty patients underwent total thyroidectomy during our study period. The ratio of males to females was 12 to 38 with each group inclusive of 25 patients (with and without routine oral calcium and vitamin $\mathrm{D}$ supplements). The clinical characteristics of the 2 groups are summarized in [Table 1]. There was no major age and sex difference between the 2 groups. The thyroid diseases of the patients included well-differentiated thyroid tumour, malignant in 39 patients

\begin{tabular}{|c|c|c|}
\hline Variable & Non-supplement & Supplement \\
\hline No. of patients & 25 & 25 \\
\hline Age (in years) & $43 \pm 2$ & $47 \pm 3$ \\
\hline $\operatorname{Sex}[M / F]$ & $5 / 20$ & $7 / 18$ \\
\hline $\begin{array}{l}\text { Thyroid disease } \\
\text { (n) Malignancy } \\
\text { Benign }\end{array}$ & 196 & 205 \\
\hline $\begin{array}{l}\text { Operation (n) } \\
\text { Total thyroidec- } \\
\text { tomy alone Total } \\
\text { thyroidectomy + } \\
\text { MRND }\end{array}$ & 178 & 187 \\
\hline $\begin{array}{l}\text { No. of parathy- } \\
\text { roid glands pre- } \\
\text { served }\end{array}$ & $2.1 \pm 1$ & $2.3 \pm 1$ \\
\hline $\begin{array}{l}\text { Temporary } \\
\text { Hypocalcemia } \\
\text { Symptomatic } \\
\text { Laboratory }\end{array}$ & 53 & 24 \\
\hline $\begin{array}{l}\text { Intravenous Cal- } \\
\text { cium }\end{array}$ & 3 & 0 \\
\hline $\begin{array}{l}\text { Permanent } \\
\text { Hypocalcemia }\end{array}$ & 1 & 1 \\
\hline
\end{tabular}

\begin{tabular}{|c|c|c|c|}
\hline Variable & $\begin{array}{l}\text { Non- } \\
\text { supplement }\end{array}$ & Supplement & P value* \\
\hline $\begin{array}{lr}\begin{array}{l}\text { Total } \\
\text { cium }\end{array} & \text { POl- } \\
\text { Day 1 } & \text { PO } \\
\text { Day3 } & \text { PO } \\
\text { Month 1 } & \end{array}$ & $\begin{array}{l}8.21 \pm 0.1 \\
8.01 \pm 0.1 \\
8.87 \pm 0.2\end{array}$ & $\begin{array}{l}8.93 \pm 0.1 \\
8.71 \pm 0.1 \\
9.33 \pm 0.2\end{array}$ & $\begin{array}{l}\text { NS } \\
0.001 \\
\text { NS }\end{array}$ \\
\hline $\begin{array}{l}\text { Intact } \mathrm{PTH} \\
\text { PO Day } 1 \\
\text { PO Day3 } \\
\text { PO Month } 1\end{array}$ & $\begin{array}{l}26.52 \pm 2.1 \\
24.93 \pm 4.0 \\
33.01 \pm 4.9\end{array}$ & $\begin{array}{l}25.22 \pm 3.9 \\
24.01 \pm 4.9 \\
35.01 \pm 4.6\end{array}$ & $\begin{array}{l}\text { NS } \\
\text { NS } \\
\text { NS }\end{array}$ \\
\hline
\end{tabular}

$\mathrm{PO}=$ Post-Operative, $\mathrm{PTH}=$ Parathyroid Hormone, $\mathrm{NS}=$ Not Significant, *test, P Value $<0.05$

and benign in 11 patients. The standard operative procedure was total thyroidectomy alone in 35 patients. The mean number of preserved parathyroid glands was 2.2. Symptomatic hypocalcemia developed in 5 patients in a group of 25 not receiving supplement and in 2 out of 25 in the supplement group. Laboratory hypocalcemia developed in 3 patients in the group which was not receiving supplements and 4 of 25 in the supplement group. The incidence of hypocalcemia was significantly lower in the supplement group than in 
the non-supplement group. ${ }^{[8]}$ Hypocalcemia symptoms were minimal in the supplement group but more severe in the nonsupplement group. Intravenous calcium was administered to 3 patients in the non-supplement group but none to patients belonging to the supplement group. Permanent hypocalcemia developed in 1 patient of both the groups. Serum calcium and iPTH levels decreased by 3 days duration after thyroidectomy and nearly completely recovered approximately 3 months after surgery in both groups. Total calcium values were measured at post-operative days 1, 3 and 1 month and were found to be lower in the group not receiving supplement than in the supplement group. However, no statistical difference was observed in the pre-operative and post-operative iPTH levels of both groups. The decrease in patient serum calcium and iPTH levels during the early days after surgery was less and the levels recovered earlier in the supplement group than in the non-supplement group. This study shows significant reduction in incidence of hypocalcemia after total thyroidectomy as the post-operative treatment helped in preventing significant reduction of serum calcium levels as well as subsequent increase with oral calcium and vitamin D supplements. ${ }^{[9,10]}$ Patients did not experience hypocalcemia in the supplement group, the symptoms were minimal. By contrast, the group that did not receive supplement, hypocalcemic symptoms were more severe. In the non-supplement group, 3 patients required intravenous calcium administration after persistent significant hypocalcemia, when they failed to respond to oral dosage of calcium and vitamin D supplements. Therefore, our data suggest that routine administration of oral calcium and vitamin D supplements can significantly reduce the incidence and severity of hypocalcemia after total thyroidectomy, even though they do not completely eliminate the occurrence of post-operative hypocalcemia. Two studies have evaluated the efficacy of routine calcium supplements for the prevention of hypocalcemia after thyroidectomy. Moore reported that only 4 of 124 patients who received daily treatment of calcium $(5 \mathrm{~g})$ after bilateral thyroid resection developed hypocalcemia and 1 required administration of intravenous calcium. ${ }^{[1]}$ The prophylacticusage of oral calcium to reduce the likelihood ofhypocalcemia and raise the possibility of early hospital discharge was suggested on the basis of scientific findings. Bellantone et al, reported in a prospective control study that only 3 of 26 patients (11\%) receiving oral calcium supplement $(3 \mathrm{~g} / \mathrm{d})$ had symptoms related to hypocalcemia after total thyroidectomy, whereas 11 of 27 patients $(40 \%)$ not receiving calcium supplement had symptoms. ${ }^{[12]}$ These studies suggest that, post-thyroidectomy hypocalcemia can be considerably prevented by the routine administration of calcium supplements. Serum calcium levels decrease in most patients early after total thyroidectomy and are secondary to the impairment of parathyroid function in most cases.

\section{Conclusion}

With our research data we found that routine oral calcium and vitamin D supplements are way more effective in reducing the incidence and severity of hypocalcemia after total thyroidectomy, which in turn will lead to improvement in satisfaction of patients and prove to be a significant cost saving step. However, further detailed studies are needed with variable dosages and durations of supplements in order to come to proper conclusion.

\section{References}

1. Moore FD. Oral calcium supplements to enhance early hospital discharge after bilateral surgical treatment of the thyroid gland or exploration of the parathyroid glands. J Am Coll Surg. 1994;178:11-16.

2. Bellantone R, Lombardi CP, Raffaelli $\mathrm{M}$, Boscherini $\mathrm{M}$, Alesina PF, Crea CD, et al. Is routine supplementation therapy (calcium and vitamin D) useful after total thyroidectomy? Surg. 2002;132(6):1109-1113. Available from: https://dx.doi.org/10. 1067/msy.2002.128617. doi:10.1067/msy.2002.128617.

3. Pattou F, Combemale F, Fabre S, Carnaille B, Decoulx M, Wemeau JL, et al. Hypocalcemia following Thyroid Surgery: Incidence and Prediction of Outcome. World J Surg. 1998;22(7):718-724. Available from: https://dx.doi.org/10. 1007/s002689900459. doi:10.1007/s002689900459.

4. Gac EP, Cabane TP, Amat VJ, Huidobro GF, Rossi FR, Rodríguez FF. Incidence of hypocalcemia after total thyroidectomy. Rev Med Chil. 2007;135:26-30.

5. Tartaglia F, Sgueglia M, Muhaya A, Cresti R, Mulas MM, Turriziani V. Complications in total thyroidectomy: Our experience and a number of considerations. ChirItal. 2003;55(2):499-510.

6. Lindblom P, Westerdahl J, Bergenfelz A. Low parathyroid hormone levels after thyroid surgery: A feasible predictor of hypocalcemia. Surg. 2002;131(5):515-520. Available from: https://dx.doi.org/10.1067/msy.2002.123005. doi:10.1067/msy.2002.123005.

7. Maitland R, Miell J. Hypocalcemia post-total thyroidectomy: A clinical experience. Endocrine. 2010;21:50-50.

8. Bellantone R, Lombardi CP, Raffaelli M, Boscherini M, Alesina PF, Crea CD, et al. Is routine supplementation therapy (calcium and vitamin D) useful after total thyroidectomy? Surg. 2002;132(6):1109-1113. Available from: https://dx.doi.org/10. 1067/msy.2002.128617. doi:10.1067/msy.2002.128617.

9. Bentrem DJ, Rademaker A, Angelos P. Evaluation of serum calcium levels in predicting hypoparathyroidism after total/near-total thyroidectomy or parathyroidectomy. Am Surg. 2001;67:249-51.

10. Bilezikian JP, Brandi ML, Cusano NE, Mannstadt M, Rejnmark L, Rizzoli R, et al. Management of Hypoparathyroidism: Present and Future. J Clin Endocrinol Metabol. 2016;101(6):2313-2324. Available from: https://dx.doi.org/10. 1210/jc.2015-3910. doi:10.1210/jc.2015-3910.

11. Al-Azem H, Khan AA. Hypoparathyroidism. Best Practice Res Clin Endocrinol Metabol. 2012;26(4):517522. Available from: https://dx.doi.org/10.1016/j.beem.2012. 
01.004. doi:10.1016/j.beem.2012.01.004.

12. Bellantone $\mathrm{R}$, Lombardi $\mathrm{CP}$, Raffaelli $\mathrm{M}$, Boscherini $\mathrm{M}$, Alesina PF, Crea $\mathrm{CD}$, et al. Is routine supplementation therapy (calcium and vitamin D) useful after total thyroidectomy? Surgery. 2002;132(6):1109-1113. Available from: https://dx.doi.org/10.1067/msy.2002.128617. doi:10.1067/msy.2002.128617.

Copyright: (C) the author(s), 2020. It is an open-access article distributed under the terms of the Creative Commons Attribution License (CC BY 4.0), which permits authors to retain ownership of the copyright for their content, and allow anyone to download, reuse, reprint, modify, distribute and/or copy the content as long as the original authors and source are cited.

How to cite this article: Reddy VSC, Vijay B. Prophylactic Calcium and Vitamin D Supplementation to Prevent Hypocalcemia Post-Thyroidectomy. Acad. J Surg. 2020;3(1):128-131.

DOI: dx.doi.org/10.47008/ajs/2020.3.1.28

Source of Support: Nil, Conflict of Interest: None declared. 